\title{
ANALISIS FAKTOR-FAKTOR YANG BERPENGARUH TERHADAP PERSEDIAAN PADA USAHA KAIN SASIRANGAN DI KOTA BANJARMASIN
}

\author{
"H. Abd. Wahab HJ"
}

Abstract: This research is aimed to analize factors that affect the inventory of Sasirangan business in Banjarmasin. The factors analized in the research are: selling amount $\left(X_{1}\right)$, product amount $\left(X_{2}\right)$, price level $\left(X_{3}\right)$, product variety $\left(X_{4}\right)$, material purchase amount $\left(X_{5}\right)$, lead time $\left(X_{6}\right)$, and inventory amount $(Y)$. For about 25 samples that meet the requirements will be taken by using the purposive sampling technique. The analysis tool that is used in this research is the multiple linear regression model; regression equations, that show the variables $X_{1}, X_{2}, X_{3}, X_{4}, X_{5}, X_{6}$, simultaneously give significant effect to variable $Y$. This is shown in the test $F$ result that the $F$ calculation (11.244) is higher than the table $F(2,66)$, and its probability value (2.947E-05) is lower than the value of alfa $(\alpha=0,05)$. While the dominant factor that affects inventory amount of Sasirangan business in Banjarmasin is the selling amount $\left(X_{1}\right)$.

Key words: selling amount, product amount, price level, product variety, material purchase amount, lead time, and inventory amount.

\section{Pendahuluan}

Perkembangan usaha kain sasirangan selama lima tahun terakhir ini menunjukan perkembangan yang semakin pesat, hal ini terlihat dari semakin bertambahnya usahausaha tersebut baik yang dikelola oleh perorangan maupun kelompok usaha. Dilihat dari pemakai atau penggunaan kain sasirangan sebagai seragam (uniform) baik di kantor pemerintahan maupun swasta, dan juga digunakan di kelompok pendidikan baik dari Sekolah dasar sampai ke Sekolah Lanjutan, serta dalam acara resmi maupun menghadiri pesta perkawinan.

Dengan adanya perkembangan tersebut mendorong semakin meningkatnya usaha dalam pengadaan dan penjualan kain sasirangan dari berbagai motif dan

bahan yang beragam dan disesuaikan dengan selera dan permintaan konsumen, yang kondisi ini menunjukan peluang bagi usaha kain sasirangan untuk mengembangkannya. Untuk memanfaatkan peluang tersebut, pengusaha memerlukan sejumlah dana yang akan diinvestasikan baik dalam bentuk aktiva tetap (peralatan atau perlengkapan) maupun aktiva lancar (kas, piutang, dan persediaan). Dana yang tertanam dalam bentuk persediaan ataupun dalam operasi usaha secara keseluruhan diharapkan dapat menghasilkan keuntungan yang sesuai dengan apa yang diharapkan.

Persediaan yang diperlukan dalam proses produksi atau operasi usaha merupakan elemen utama dari modal kerja (aktiva lancar) yang selalu dalam keadaan berputar, serta secara terus menerus mengalami perubahan. Perputaran tersebut dimulai pada saat dana/kas yang diinvestasikan pada persediaan yang selanjutnya dipergunakan dalam proses produksi atau dijual, dan hasil penjualan ini diinvestasikan lagi dalam bentuk persediaan.

Cepat lambatnya perputaran persediaan menjadi kas akan sangat tergantung pada kebijakan penjualan (tunai atau kredit). Seperti yang dikemukakan oleh Bambang Riyanto (2010) tentang siklus aktiva lancar sebagai berikut: 


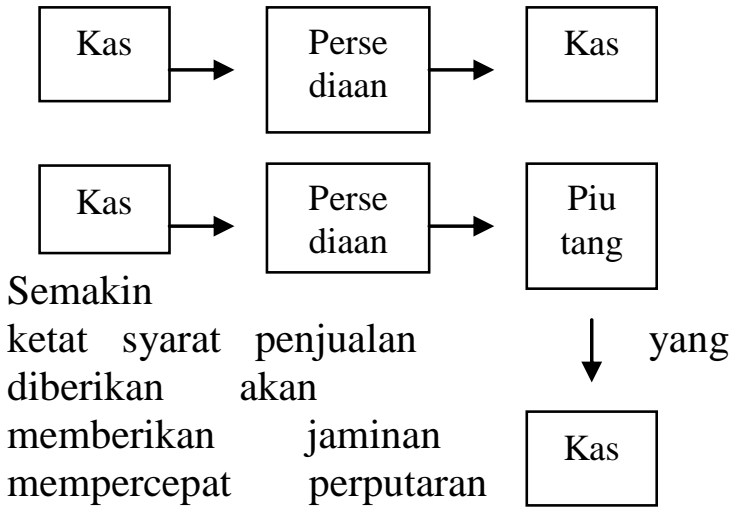

dari persediaan, demikian juga sebaliknya bila syarat pembayaran lunak maka semakin lama periode terikatnya dana kembali menjadi persediaan.

Sebagaimana dikemukakan oleh Sofyan Assauri (2013) bahwa rata-rata perputaran persediaan memperlihatkan bagaimana efektifnya total dana yang diinvestasikan dalam persediaan.

Makin tinggi tingkat perputaran persediaan, berarti semakin cepat pula perputaran dana dari persediaan menjadi kas, sehingga makin pendek periode terikatnya dana dalam bentuk persediaan.

Sesuai dengan konsep manajemen persediaan kemudian dengan mengidentifikasi faktor yang diperkirakan mempunyai pengaruh terhadap jumlah persediaan, yang selanjutnya faktor-faktor tersebut dimasukan dalam bentuk model yang spesifik sebagai suatu upaya untuk mengoptimalkan persediaan yang dilakukan oleh usaha kain sasirangan.

\section{Perumusan Masalah}

Melalui studi kepustakaan dan penelitian lapangan dapat diidentifikasi beberapa faktor yang dipandang berpengaruh terhadap jumlah persediaan kain sasirangan, sehingga masalah yang dianalisis dalam penelitian ini dirumuskan yaitu: apakah faktor jumlah penjualan, jumlah produksi, tingkat harga, jenis produk, jumlah pembelian bahan baku, dan lead time berpengaruh terhadap persediaan pada usaha kain sasirangan di kota Banjarmasin, dan dari faktor-faktor tersebut manakah faktor yang dominan yang berpengaruh terhadap persediaan.

\section{Manfaat Penelitian}

Dengan mengetahui faktor-faktor yang berpengaruh dan faktor yang dominan pengaruhnya, diharapkan informasi ini dapat dijadikan sebagai bahan pertimbangan bagi pemilik dan pengusaha kain sasirangan dalam rangka penyusunan kebijakan persediaan kain sasirangan, sehingga terciptanya suatu keseimbangan antara investasi dana dalam persediaan dan pemenuhan permintaan konsumen.

\section{Tinjauan Teoritis}

Menurut T. Hani Handoko (2012) pada hakekatnya persediaan adalah sesuatu atau sumberdaya-sumberdaya organisasi yang disimpan dalam antisipasinya terhadap pemenuhan permintaan.

Sofyan Assauri (2013) mengatakan bahwa persediaan adalah aktiva yang meliputi barang-barang yang dimiliki perusahaan dengan maksud untuk dijual dalam suatu periode normal atau barangbarang yang masih dalam proses produksi maupun persediaan bahan baku yang menunggu penggunaannya dalam suatu proses produksi.

Sedangkan menurut Schroeder (2009) menyatakan "an inventory is a stock of materials used to facilitate production or to satisfy customer demand".

Sementara menurut Munandar (2008) menyatakan bahwa persediaan adalah sebagai persediaan barang-barang (bahan-bahan) yang menjadi obyek usaha pokok.

Menurut Brealey and Myers (2008) secara umum persediaan dapat dikatagorikan dalam tiga jenis, yaitu persediaan bahan mentah, barang dalam proses dan persediaan produksi jadi yang siap dijual dan dikirim. Kategori ini berlaku bagi perusahaan-perusahaan industri pengolahan.

Mannes (2008) menyatakan bahwa dari titik pandang seorang manajer keuangan investasi dalam persediaan selalu dihubungkan dengan kebutuhan 
persediaan, biaya penyimpanan persediaan, dan biaya pemesanan per unit. Untuk itulah maka seorang manajer keuangan ikut bertanggung jawab dalam pengambilan keputusan menyangkut berapa besar persediaan yang harus disiapkan untuk memenuhi permintaan konsumen, kapan disiapkan, bagaimana menyiapkannya,

bagaimana membiayainya, berapa banyak bahan atau barang yang seharusnya dipesan atau diproduksi untuk memenuhi permintaan atau kebutuhan dalam suatu periode tertentu, dan berapa lama tenggang waktu antara pemesanan dan penerimaan.

\section{Metode Penelitian}

Berdasarkan latar belakang dan permasalahan yang tekah dirumuskan, serta tinjauan pustaka, maka variabel yang dianalisis dalam penelitian ini terdiri dari variabel tergantung (dependent variabel) yaitu jumlah persediaan kain sasirangan yang disebut sebagai variabel $\mathrm{Y}$, dan variabel bebas (independent variabel) disebut variabel $\mathrm{X}$ yang teridiri dari; $\mathrm{X}_{1}=$ jumlah penjualan, $X_{2}=$ jumlah produksi, $\mathrm{X}_{3}=$ tingkat harga, $\mathrm{X}_{4}=$ jenis produksi, $\mathrm{X}_{5}$ $=$ jumlah pembelian bahan, dan $\mathrm{X}_{6}=$ waktu tunggu.

Jenis data yang dikumpulkan adalah data kuantitatif dan kualitatif yang bersumber dari data sekunder dan primer, yang didapat melalui wawancara dan pengamatan (observasi) ke usaha kain sasirangan dan juga dari kantor instansi terkait seperti Kantor Statistik dan Kantor Perindustrian dan Perdagangan Kota Banjarmasin.

Populasi adalah seluruh usaha kain sasirangan yang ada di kota Banjarmasin, sedangkan sampel diambil secara purposive sampling atau judgement sample (Masri Singarimbun dan Sofyan Efendi; 2009) menyatakan bahwa pengambilan sampel yang bersifat tidak acak di mana sampel dipilih berdasarkan pertimbangan tertentu. Kriteria yang dipergunakan; bahwa usaha tersebut sudah beroperasi suda lima tahun; usaha merupakan usaha pokok bukan usaha sampingan, dan usaha tersebut mengolah dan menjual kain sasirangan dari berbagai macam jenis kain dan motif. Berdasarkan kriteria tersebut dipilih 25 buah usaha kain sasirangan yang menjadi sampel.

Teknik yang digunakan dengan analisis statistika dengan menggunakan analisis regresi linier multiple yang didasarkan pada gabungan data cross section dan data series, dengan model;

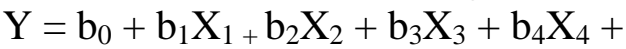

$$
b_{5} X_{5}+b_{6} X_{6}+e_{i}
$$

Dimana;

$\mathrm{Y}=$ jumlah penjualan

$\mathrm{b}_{0}=$ konstanta

$\mathrm{X}_{1}=$ jumlah penjualan $\quad \mathrm{X}_{2}=$

jumlah produksi

$\mathrm{X}_{3}=$ tingkat harga $\quad \mathrm{X}_{4}=$

jenis produksi

$\mathrm{X}_{5}=$ jumlah pembelian bahan $\quad \mathrm{X}_{6}=$ waktu tunggu

$\mathrm{e}_{\mathrm{i}}=$ variabel gangguan/error

$b_{1} \ldots b_{6}=$ koefisien regresi

Penggunaan model regresi tersebut, haruslah memenuhi asumsi-asumsi klasik yang mendasari model regresi, yang dalam ekonometri dinamakan Best Linier Unbiased Estimator/BLUE. (Djoko Mursinto, 2000). Untuk membuktikan hipotesis pertama dihitung koefisien korelasi multiplenya dengan rumus (Sudjana, 1983), yaitu; $\mathrm{R}=\sqrt{ }$ (JK.reg) / $\Sigma Y^{2}$

Untuk membuktikan apakah koefisien korelasi multiple-nya signifikan atau tidak dilakukan dengan uji $\mathrm{F}$, dengan rumus sebagai berikut;

$$
\mathrm{F}=\left(\mathrm{R}^{2} / \mathrm{k}\right) /\left[\left(1-\mathrm{R}^{2}\right) /(\mathrm{n}-\mathrm{k}-1)\right]
$$

Hipotesis diterima bila $\mathrm{F}$ hitung lebih besar dari $\mathrm{F}$ tabel atau diperoleh harga $p<0,05$. Sedangkan hipotesis kedua masing-masing koefisien regresinya diuji dengan menggunakan uji t, ( Sudjana, 1983);

$$
\begin{aligned}
\mathrm{t}= & {\left[\mathrm{r}_{\mathrm{yi}} 12 . .(\mathrm{i}-1)(\mathrm{i}+1) . . \mathrm{k} \sqrt{ } \mathrm{n}-\mathrm{k}-1\right] /[\sqrt{ } 1-} \\
& \left.\mathrm{r}_{\mathrm{yi}} 12 . .(\mathrm{i}-1)(\mathrm{i}+1) . . \mathrm{k}\right]
\end{aligned}
$$

Hasil uji t bermakna bila diperoleh $\mathrm{t}$ hitung lebih besar dari $\mathrm{t}$ tabel atau 
diperoleh harga $\mathrm{p}<0,05$, pengaruh yang dominan ditentukan oleh harga $\mathrm{p}$ yang terkecil atau $\mathrm{r}^{2}$ partial yang terbesar.

\section{Hasil Penelitian}

Seperti telah dikemukakan terdahulu bahwa faktor-faktor yang diidentifikasi berpengaruh terhadap persediaan pada usaha kain sasirangan di kota Banjarmasin, dari hasil penelitian tentang faktor-faktor tersebut sebagai berikut:

1. Jumlah penjualan $\left(\mathrm{X}_{1}\right)$ yang dicapai oleh usaha kain sasirangan selama periode penelitian yang diukur dalam total penjualan selama enam bulan yang dinyatakan dalam satuan meter, bahwa sebanyak 15 buah usaha menjual diatas rata-rata jumlah penjualan dari sampel penelitian yaitu antara 2250 meter sampai dengan 3750 meter.

2. Jumlah produksi $\left(\mathrm{X}_{2}\right)$ yang dihasilkan dari berbagai motif dan warna selama periode penelitian menunjukan bahwa 17 buah usaha kain sasirangan memproduksi di atas rata-rata yaitu sebanyak 2250 meter sampai dengan 3750 meter, sisanya sebanyak 8 buah usaha memproduksi di bawah rata-rata yaitu dengan jumlah antara 750 meter sampai dengan 2250 meter.

3. Tingkat harga $\left(X_{3}\right)$ yaitu harga jual rata-rata yang ditawarkan dari semua macam produksi, yaitu harga yang ditawarkan antara Rp.45.000,- sampai dengan Rp.65.000,- per meter.

4. Jenis produksi $\left(\mathrm{X}_{4}\right)$ yaitu motif atau bahan yang digunakan dalam produksi, bahwa bahan yang digunakan dan motif yang diproduksi satu sama lainnya ada perbedaan, hal ini dikarenakan banyaknya permintaan (pesanan) tentang bahan dan motif yang diinginkan/diminati/yang disukai, seperti bahan dari satin, sarmila, sutra, volissima, santung dan lainnya.

5. Jumlah pembelian $\left(\mathrm{X}_{5}\right)$ yaitu jumlah kain yang digunakan sebagai bahan kain sasirangan, dari data diperoleh bahwa sebanyak 17 buah usaha melakukan pembelian dengan jumlah antara 2250 meter sampai dengan 3750 meter, dan 8 buah jumlah pembeliannya antara $750-2250$ meter.

6. Waktu tunggu $\left(\mathrm{X}_{6}\right)$ adalah jangka waktu menunggu datangnya bahan yang dipesan tiba di tempat usaha, dari data diperoleh bahwa kisaran waktu tunggu antara 1 hari sampai dengan 8 hari, di mana sebanyak 21 buah usaha waktu tunggunya antara 1 hari sampai 4 hari, sisanya 4 buah usaha waktu tunggunya antara 4 sampai dengan 8 hari.

7. Jumlah persediaan (Y) adalah jumlah produk atau kain sasirangan yang tidak habis terjual selama periode waktu tertentu, yang dalam hal ini adalah jumlah persediaan rata-ratanya. Dari data yang diperoleh menunjukan bahwa rata-rata jumlah persediaan berkisar antara 10 meter sampai dengan 60 meter, sebanyak 15 buah usaha jumlah persediaanya di atas ratarata yaitu berkisar antara 30 meter sampai dengan 60 meter.

\section{Analisis}

Dengan menggunakan model analisis regresi berganda dengan alat bantu komputer dengan program microstat diperoleh hasil seperti pada tabel berikut ini. 
Tabel

Rekapitulasi Hasil Regersi Berganda dari Variabel yang Berpengaruh Terhadap Jumlah Persediaan pada Usaha Kain Sasirangan di Kota Banjarmasin

\begin{tabular}{|c|l|r|r|r|r|c|}
\hline No. & \multicolumn{1}{|c|}{ Variabel } & \multicolumn{1}{|c|}{ Koef.Reg. } & \multicolumn{1}{c|}{ T hitung } & Prob. & $\mathrm{r}^{2}$ parsial & Ket \\
\hline 1. & $\mathrm{X}_{1}$ Jumlah Penjualan & -0.8329 & -5.619 & 0.00002 & 0.6369 & $\mathrm{~S}$ \\
2. & $\mathrm{X}_{2}$ Jumlah Produksi & 0.7400 & 5.441 & 0.00004 & 0.6218 & $\mathrm{~S}$ \\
3. & $\mathrm{X}_{3}$ Tingkat Harga & 0.0838 & 0.360 & 0.72335 & 0.0071 & $\mathrm{TS}$ \\
4. & $\mathrm{X}_{4}$ Jenis Produksi & 1.8140 & 1.302 & 0.20949 & 0.0860 & $\mathrm{TS}$ \\
5. & $\mathrm{X}_{5}$ Jumlah Pembelian & 0.0919 & 5.011 & 0.00009 & 0.5824 & $\mathrm{~S}$ \\
6. & $\mathrm{X}_{6}$ Waktu Tunggu & -0.5679 & -0.602 & 0.55453 & 0.0198 & $\mathrm{TS}$ \\
7. & Constanta & -5.5294 & & & & \\
\hline
\end{tabular}

R Square $=0.7894 \quad$ F ratio $\quad=11.244 \quad \mathrm{~S}=$ Signifikan

Multiple R $=0.8885$ Probabilitas $\quad=2.947 \mathrm{E}-05 \mathrm{TS}=$ Tidak Signifikan

Dari 6 (enam) variabel bebas yang dimasukkan dalam model regresi berganda menunjukan koefisien regresi masingmasing variabel seperti pada tabel tersebut menunjukan hasil bahwa koefisien regresi jumlah penjualan $\left(\mathrm{X}_{1}\right)-0,8329$, koefisien regresi jumlah produksi $\left(\mathrm{X}_{2}\right)$ 0,7400, koefisien regresi tingkat harga $\left(\mathrm{X}_{3}\right)$ 0,0839, koefisien regresi jenis produksi $\left(\mathrm{X}_{4}\right)$ 1,8140 , koefisien regresi jumlah pembelian (X) 0,0919, koefisien regresi waktu tunggu $\left(\mathrm{X}_{6}\right)-0,5679$.

Hasil koefisien determinasi $\left(\mathrm{R}^{2}\right)$ sebesar 0,7894 hasil ini menunjukan bahwa variabel bebas dapat menjelaskan variabelitas variabel tidak bebas (jumlah persediaan), sedangkan sisanya 0,2106 dijelaskan oleh faktor yang tidak terliput dalam model.

Dari hasil uji $\mathrm{F}$ didapatkan $\mathrm{F}$ ratio sebesar 11.244 lebih besar jika dibandingkan dengan $\mathrm{F}$ tabel 2,66 pada taraf nyata alpa 0,05 . Hasil ini menunjukan bahwa variabel jumlah penjualan, jumlah produksi, tingkat harga, jenis produksi, jumlah penjualan, dan waktu tunggu secara bersama-sama mempunyai pengaruh yang signifikan terhadap jumlah persediaan, dengan demikian hipotesis pertama diterima.

Dilihat dari perhitungan pengaruh secara parsial dari variabel bebas menunjukan bahwa dari 6 (enam) variabel bebas yang terbesar $\mathrm{r}^{2}$ parsialnya adalah variabel jumlah penjualan $\left(\mathrm{X}_{1}\right)$ yaitu
0,6369 terbesar dari variabel bebas lainnya, dengan demikian hipotesis yang kedua juga diterima. Dimana jumlah penjualan mempunyai pengaruh dominan terhadap jumlah persediaan.

Dengan diterimanya hipotesis, maka faktor-faktor yang relevan untuk dipertimbangkan dalam menganalisis faktor yang berpengaruh terhadap jumlah persediaan adalah faktor-faktor jumlah penjualan, jumlah produksi, tingakt harga, jenis produksi, jumlah pembelian, dan waktu tunggu secara bersama-sama. Namun secara parsial hanya ada 3 (tiga) variabel yang signifikan yaitu jumlah penjualan, jumlah produksi, dan jumlah pembelian bahan, sedangkan 3 (tiga) faktor lainnya seperti tingkat harga, jenis produksi, dan waktu tunggu tidak siginifikan pengaruhnya terhadap jumlah persediaan.

Analisis lebih lanjut terhadap hasil perhitungan pada model regresi berganda seperti pada tabel tersebut:

1. Jumlah penjualan mempunyai koefisien regresi sebesar $-0,8329$ dan bertanda negatif, berarti pengaruhnya tidak searah/bertolak belakang, sesuai dengan teori bahwa bila jumlah barang yang dijual meningkat maka persediaan akan berkurang, sebaliknya bila penjualan menurun maka jumlah persediaan banyak. Kemudian dari hasil $t$ hitung menunjukan bahwa hasil t hitung sebesar - 5,619 lebih besar 
bila dibandingkan dengan t tabel 1,711, hal ini menunjukkan bahwa variabel ini mempunyai pengaruh yang signifikan terhadap jumlah persediaan.

2. Jumlah produksi koefisiennya sebesar 0,7400 dan bertanda positif, artinya pengaruhnya terhadap jumlah persediaan adalah searah, bila jumlah rpduksi bertambah maka jumlah persediaan juga bertambah. Hasil $t$ hitung menunjukan 5,441 lebih besar dari $\mathrm{t}$ tabel 1,711 ini menunjukan bahwa variabel jumlah produksi juga mempunyai pengaruh yang signifikan terhadap jumlah persediaan.

3. Tingkat harga, koefisien regresinya sebesar 0,0838 dan bertanda positif, artinya variabelitasnya searah dengan jumlah persediaan, namun bila dilihat dari t hitungnya sebesar 0,360 lebih kecil dari $\mathrm{t}$ tabel 1,711, hal ini menunjukan bahwa variabel ini tidak signifikan pengaruhnya terhadap jumlah persediaan. Tidak signifikan bisa dimungkinkan karena harga yang ditawarkan oleh usaha kain sasirangan memang harga pasar dan konsumen sudah mengetahui dan tidak jauh berbeda dengan ahrga masing-masing usaha kain sasirangan.

4. Jenis Produksi; nilai koefisien regresinya 1,8140 dan nilai t hitunnya 1,302 lebih kecil dari t tabel 1,711, hal ini menunjukan bahwa jenis produksi tidak signifikan pengaruhnya terhadap jumlah persediaan. Jenis produksi atau motif yang ditawarkan oleh masingmasing usaha kain sasrirangan memang sesuai dengan keinginan atau pesanan, serta bahan dan motif yang dibuat memang demikian adanya.

5. Jumlah pembelian; nilai koefisien regesinya 0,0919 dan bertanda positif artinya pengaruhnya searah terhadap jumlah persediaan, bial jumlah pembelian bertambah maka jumlah persediaan juga bertambah. Dilihat dari t hitungnya sebesar 5,011 lebih besar dibandingkan dengan $\mathrm{t}$ tabel 1,711 berarti variabel ini mempunyai pengaruh yang signifikan terhadap jumlah persediaan.

6. Waktu tunggu; nilai koefisien regresinya - 0,5679 dan inilai $t$ hitungnya sebesar - 0,602 lebih kecil dibanding dengan $t$ tabel 1,711 berarti variabel waktu tunggu tidak signifikan pengaruhnya terhadap jumlah persediaan. Tidak signifikan bisa mungkin dikarenakan pesanan yang dilakuan selalu tepat waktu kedatangannya sehingga tidak mengganggu persediaan yang ada dan tidak berpengaruh terhadap kegiatan proses produksi.

\section{Simpulan}

Berdasarkan hasil penelitian, analisis data yang telah diuraikan menunjukan hawa hasil perhitungan dan pengujian dengan uji $\mathrm{F}$ terhadap model yang digunakan dalam menganalisis faktor-faktor yang berpengaruh terhadap persediaan menunjukan $\mathrm{F}$ hitung 11,244 lebih besar dari $F$ tabel 2,66, hal ini menunjukan bahwa hipotesis pertama diterima, artinya variabel bebas secara bersama-sama mempunyai pengaruh yang signifikan terhadap variabel tidak bebasnya.

Kemudian dari 6 variabel bebas dari hasil uji t menunjukan bahwa variabel jumlah penjualan ( $\mathrm{t}$ hitung - 5,619) yang terbesar, sehingga variabel ini yang domnian pengaruhnya terhadap jumlah penjualan artinya hipotesis kedua juga diterima.

Bila dilihat secara parsial hanya tiga variabel dari enam variabel bebasnya yang signifikan pengarunhya terhadap variabel jumlah persediaan, yaitu jumlah penjualan, jumlah produksi, dan jumlah pembelian, sedangkan tiga variabel lainnya tidak signifikan pengaruhnya terhadap jumlah persediaan. Namun dalam rangka pengambilan keputusan untuk menentukan jumlah persediaan secara bersama-sama perlu mendapat perhatian, dan yang perlu diperhatikan adalah jumlah penjualan agar dapat bisa ditingkatkan atau minimal bisa dipertahankan dengan melakukan usaha 
pemasaran, yaitu dengan membuka daerah pemasaran yang baru, ikut serta dalam pameran bersama daru usaha kain sasirangan baik di daerah maupun luar daerah.

\section{DAFTAR PUSTAKA}

Ahyari, Agus, 2012, Manajemen Produksi, BPFE UGM, Yogyakarta.

Assauri, Sofyan, 2013, Manajemen Produksi, LPFE UI, Jakarta.

Brealey, Richard and S. Myers., 2008, Principles of Corporate Finance, Third Edition, McGraw Hill Book, Co., Singapore.

Handoko, T. Hani, 2012, Dasar-Dasar Manajemen Produksi Dan Operasi, BPFE UGM, Yogyakarta.

Mannes, S. Terry, 2008, Introduction to Corporate Finance, McMillan, Singapore.

Munawir, S., 2007, Analisa Laporan Keuangan, Cetakan kedua, Penerbit Liberty, Yogyakarta.

Munandar, M., 2007, Pokok-Pokok Intermediate Accounting, Cetakan Ketiga, Jakarta.

Mursinto, Djoko, 2000, Ekonometri Salah Satu Alat Analisis Ekonomi, FE Unair, Surabaya.

Riyanto, Bambang, 1997, Dasar-dasar Pembelanjaan Perusahaan, Edisi ke Tiga, Cetak an ke Duabelas, Yayasan Badan Penerbit Gajah Mada, Yogyakarta
Schroeder, Roger G. 2009, Operation Management, Third Edition, MsGraw Hill Book,

Co, Singapore.

Singarimbun, Masri dan Sofyan Effendi, 2009, Metode Penelitian Survey, LP3ES, Jakarta 
Lampiran

Tabel

HASIL PENELITIAN DARI VARIABEL YANG DIANALISIS

\begin{tabular}{|c|c|c|c|c|c|}
\hline No. & Variabel & & saran & Jlh perusahaan & $\%$ \\
\hline \multirow[t]{6}{*}{1.} & $\mathrm{X}_{1}$ Jumlah Penjualan (satuan meter) & 750.00 & $<1250.00$ & 6 & 24.00 \\
\hline & & 1250.00 & $<1750.00$ & 2 & 8.00 \\
\hline & & 1750.00 & $<2250.00$ & 2 & 8.00 \\
\hline & & 2250.00 & $<2750.00$ & 8 & 32.00 \\
\hline & & 2750.00 & $<3250.00$ & 6 & 24.00 \\
\hline & & 3250.00 & $<\quad 3750.00$ & 1 & 4.00 \\
\hline \multirow[t]{6}{*}{2.} & $\mathrm{X}_{2}$ Jumlah Produksi (satuan meter) & 750.00 & $<1250.00$ & 6 & 24.00 \\
\hline & & 1250.00 & $<1750.00$ & 2 & 8.00 \\
\hline & & 1750.00 & $<2250.00$ & 2 & 8.00 \\
\hline & & 2250.00 & $<2750.00$ & 7 & 28.00 \\
\hline & & 2750.00 & $<3250.00$ & 7 & 28.00 \\
\hline & & 3250.00 & $<3750.00$ & 1 & 4.00 \\
\hline \multirow[t]{4}{*}{3.} & $\mathrm{X}_{3}$ Tingkar Harga (rupiah) & 25000.00 & $<35000.00$ & 1 & 4.00 \\
\hline & & 35000.00 & $<45000.00$ & 0 & 0.00 \\
\hline & & 45000.00 & $<55000.00$ & 14 & 56.00 \\
\hline & & 55000.00 & $<65000.00$ & 10 & 40.00 \\
\hline \multirow[t]{4}{*}{4.} & $\mathrm{X}_{4}$ Jenis Produksi (satuan jenis) & 3.00 & $<4.00$ & 2 & 8.00 \\
\hline & & 4.00 & $<5.00$ & 10 & 40.00 \\
\hline & & 5.00 & $<6.00$ & 1 & 4.00 \\
\hline & & 6.00 & $<7.00$ & 12 & 48.00 \\
\hline \multirow[t]{6}{*}{5.} & $\mathrm{X}_{5}$ Jumlah Pembelian (satuan meter) & 750.00 & $<1250.00$ & 4 & 16.00 \\
\hline & & 1250.00 & $<1750.00$ & 4 & 16.00 \\
\hline & & 1750.00 & $<2250.00$ & 2 & 8.00 \\
\hline & & 2250.00 & $<2750.00$ & 7 & 28.00 \\
\hline & & 2750.00 & $<3250.00$ & 6 & 24.00 \\
\hline & & 3250.00 & $<\quad 3750.00$ & 2 & 8.00 \\
\hline \multirow[t]{7}{*}{6.} & $\mathrm{X}_{6}$ Waktu Tunggu (satuan hari) & 1.00 & $<2.00$ & 3 & 12.00 \\
\hline & & 2.00 & $<3.00$ & 12 & 48.00 \\
\hline & & 3.00 & $<4.00$ & 6 & 24.00 \\
\hline & & 4.00 & $<5.00$ & 1 & 4.00 \\
\hline & & 5.00 & $<6.00$ & 1 & 4.00 \\
\hline & & 6.00 & $<7.00$ & 1 & 4.00 \\
\hline & & 7.00 & $<8.00$ & 1 & 4.00 \\
\hline \multirow[t]{5}{*}{7.} & Y Jumlah Persediaan (satuan meter) & 10.00 & $<20.00$ & 1 & 4.00 \\
\hline & & 20.00 & $<30.00$ & 9 & 36.00 \\
\hline & & 30.00 & $<40.00$ & 3 & 12.00 \\
\hline & & 40.00 & $<\quad 50.00$ & 6 & 24.00 \\
\hline & & 50.00 & $<60.00$ & 6 & 24.00 \\
\hline
\end{tabular}

Sumber: diolah dari hasil penelitian 